\title{
Numerical Verification on the Algorithms for Truncation Selection within or across \\ Age Classes in a Population with Overlapping Generations
}

\author{
Abdul Ghaffar * and Hiroshi Shimizu \\ Department of Animal Science, Faculty of Agriculture, \\ Hokkaido University, Kita-ku, Sapporo-shi 060
}

(Received January 25, 1993)

\begin{abstract}
A Monte Carlo simulation study was carried out to verify the algorithms described to select the animals within and/or across the age classes to reduce the average ages and to maximize the genetic responses to truncation selection. Seven selection schemes (SSs) on two paths (bulls' sires and bulls' dams) were framed to verify and assess the implications of previously proposed (SS 3 and SS 4) theoretical algorithms. Three statistics, average ages, genetic values of selected animals and their respective standard errors, were used as criteria for numerical verification of the algorithms. Theoretical and numerical values for average ages of selected animals and genetic responses were in good agreement in their respective schemes which confirmed the proposed algorithms. The average ages and yearly genetic responses were youngest and highest, respectively, in SS 4 followed by SS 3 or SS 6 and SS 2 or SS 5. The algorithms were found satisfactory within different ranges of accuracy of selection and genetic differences among age classes. The differences among schemes became more obvious for higher genetic differences among cohorts, lower accuracy of selection and larger number of age classes.
\end{abstract}

Anim. Sci. Technol. (Jpn.) 64 (8): 771-779, 1993

Key words : Monte Carlo simulation, selection across cohorts, average ages, genetic response, overlapping generations

The age structures (generation length) and genetic responses can easily be calculated when the selection has already been occurred from the recorded data. However, predicting the age structures and genetic responses at the planning stage has been the subject of interest among animal breeders. Dickerison and $\mathrm{HAZEL}^{2)}$ described the relationship between age structure and rate of response while their expression was put into its more familiar form by RENDEL and Robertson ${ }^{11)}$. Bichard et al. ${ }^{13}$ reported the genetic superiority of progeny from younger parents than older parents and described the theory of how to select larger proportions of younger animals in a population with overlapping generations. GHAFFAR and SHIMIZU $^{5)}$ revealed, through computer simulation, the possible bias in the parental age structures due to selection of the progeny from different parents belonging to different age classes in two generations (from grand parents to grand progeny).

The offspring which are potential candidates for selection as a parents of the next genera-

* on leave from Animal Sciences Institute, NARC, Islamabad, 45500, Pakistan.

Anim. Sci. Technol. (Jpn.) 64 (8) : 771-779 771 
tion, are the progeny from parents of different ages in the population where generations overlap. They are expected to be of different average genetic merits if any genetic trend exists as a result of the selection process. BICHARD et al. "' computed the truncation point (s) by trial and error from FisHer and Yates's "Table of Probits. Recently, DUCROCQ and QUAAS ${ }^{3)}$ presented an algorithm for computing the common truncation point across the cohorts for selection on selection index predictor, and demonstrated the interdependence of genetic merits and average ages in the four paths of selection. SHImizu and GHAFFAR $^{12}$ extended their algorithm for selccting at separate truncation points on phenotypic values specific to each age class such that predicted genetic values at truncation points of selection, or average predicted genetic values of selected parents, are the same across the age classes. The objective of this Monte Carlo simulation study was to verify the extended theoretical algorithms and assess their application for selecting breeding stock with overlapping generations.

\section{Materials and Methods}

Assumed parameters and variables: Genetic and population parameters used in the simulation are presented in Table 1. The genetic differences among age classes and accuracy of selection ( $r$ ) were assumed to be 4 levels with constant differences among age classes and 3 levels with same values across age classes, respectively. Two paths of selection, bulls' sires (bulls to breed young bulls path) and bulls' dams (cows to breed young bulls path), were considered to examine the effects of the number of candidates and selected on the verification of proposed algorithms.

Generation of population: The performance records were generated according to the same following model as in previous paper ${ }^{57}$ :

$$
\mathrm{X}_{\mathrm{ij}}=\mathrm{m}_{\mathrm{i}}+\mathrm{a}_{\mathrm{ij}}+\mathrm{e}_{\mathrm{ij}}
$$

where $X_{i j}$ refers to the performance of candidate $\mathrm{j}$ from parental age class $\mathrm{i}, \mathrm{m}_{\mathrm{i}}$ to the average genetic merits of parental age class $i$, $a_{i j}$ to additive genetic values of candidate $j$ in age class $i$ and is normally and independently distributed with $\mathrm{N}(0,1)$, and $e_{i j}$ to environ-

Table 1. Input parameters used in this simulation

\begin{tabular}{ll}
\hline \multicolumn{1}{c}{ Variables } & \multicolumn{1}{c}{ values } \\
\hline $\begin{array}{l}\text { Genetic parameters } \\
\text { Genetic variance }\end{array}$ & 1.0 \\
Accuracy of selection ( $\mathrm{r}$ ) ; 3 levels & $0.5,0.7,0.9$ \\
Genetic differences among age classes; 4 levels & $0.05,0.10,0.15,0.20$ \\
(genetic standard deviation units; gsd) & \\
Population parameters & $1 / \mathrm{r}^{2}$ \\
Phenotypic variance & $\left(1-\mathrm{r}^{2}\right) / \mathrm{r}^{2}$ \\
Environmental variance & 5,6 years \\
Bulls' sires path & $0.5,0.5$ \\
Age of candidates (2 age classes) & $4 / 200$ \\
and their proportion a cross age classes & 2 years \\
Selection pressure (number of selected/candidates) & \\
usage period & $200 / 1600$ \\
Bulls' dams path & $3-10$ years \\
Selection pressure (number of selected/cadidates) & 0.80 \\
Age of candidates ( 8 age classes) & \\
Stayability from a year to next year & \\
\hline
\end{tabular}


mental deviation with $\mathrm{N}\left(0,\left(1-\mathrm{r}^{2}\right) / \mathrm{r}^{2}\right)$.

Selection schemes: Seven truncation selection schemes (SSs) were framed to explore the theoretical and practical aspects of algorithms as following :

(1) selection within each age class at the same proportions as those of candidates' distribution across the age classes : SS 1

(2) selection of theoretical proportions within each age class so as to select, at the common truncation point on phenotypic values across the age classes : SS 2

(3) selection of theoretical proportions within each age class at age-specific truncation points so as to select on the same predicted genetic values across the age classes : SS 3

(4) selection of theoretical proportions within each age class at age-specific truncation points so as to select on the same average predicted genetic values of selected parents across the age classes : SS 4

(5) selection on gencrated phenotypic values across age classes : SS 5

(6) selection on estimated (from generated phenotypic values) genetic values across age classes : SS 6

(7) selection on the generated true breeding values across age classes : SS 7 .

The theoretical proportions and theoretical average genetic values of selected animals for the first four and the last one were computed employing the procedures described by SHIMIzU and GHAFFAR ${ }^{12)}$. However, for ready reference the general equation for predicting the theoretical genetic values $(\mathrm{g})$ is given below.

$$
\mathrm{g}=\sum \mathrm{p}_{\mathrm{i}}\left(\mathrm{I}_{\mathrm{i}} \mathrm{r}_{\mathrm{i}}+\mathrm{m}_{\mathrm{i}}-\mathrm{m}_{\mathrm{c}}\right)
$$

where $p_{i}, I_{i}, r_{i}$, and $m_{i}$ refer to the across-age proportion of selected animals, selection intensity, accuracy of selection and average genetic means before selection in the $i$-th age class, respectively, and subscript $c$ refers to the youngest age class. Simulated average genetic values of selected animals were computed from their generated breeding values.

Selection was based on the generated phenotypic values within (SS 1 and SS 2) or across (SS 5) the age classes, on the estimated genetic values within (SS 3 and SS 4) or across (SS 6) the age classes and on the generated true genetic values (SS 7) across the age classes. The generated candidates were ranked according to their individual performance within or across the age classes depending on the selection schemes.

Three statistics, proportions of selected animals among parental ages (average ages of parents), average genetic values of selected animals and their respective standard errors were computed through 20 replicates of simulation incorporating all assumed variable factors for seven schemes. These realized values were compared with theoretical values to verify the algorithms for all the schemes, specifically SS 2 and SS 3 with SS 5 and SS 6, which are the realizations of SS 2 and SS 3 , respectively.

\section{Results}

Age structures: Selection in SS 1 through SS 4 was carried out within age classes on the theoretical proportions computed by their respective algorithms ${ }^{12)}$, so average ages of selected animals did not oscillate among the replicates. Consequently, these average ages may be seen as serving theoretical and simulated values for themselves. The average ages in SS 2 and SS 3 are also theoretical values for SS 5 and SS 6, respectively. On the path of bulls' dams where the number of potential candidates and selected animals were comparatively large, the average ages of selected animals (bulls' dams) in SS 2 and SS 3 were in good agreement with those of selected in SS 5 and SS6, respectively, for each factor considered in this study (Fig. 1). However, on the path of bulls' sires where the numbers of potential candidates and selected animals were relatively small, the differences in the average 

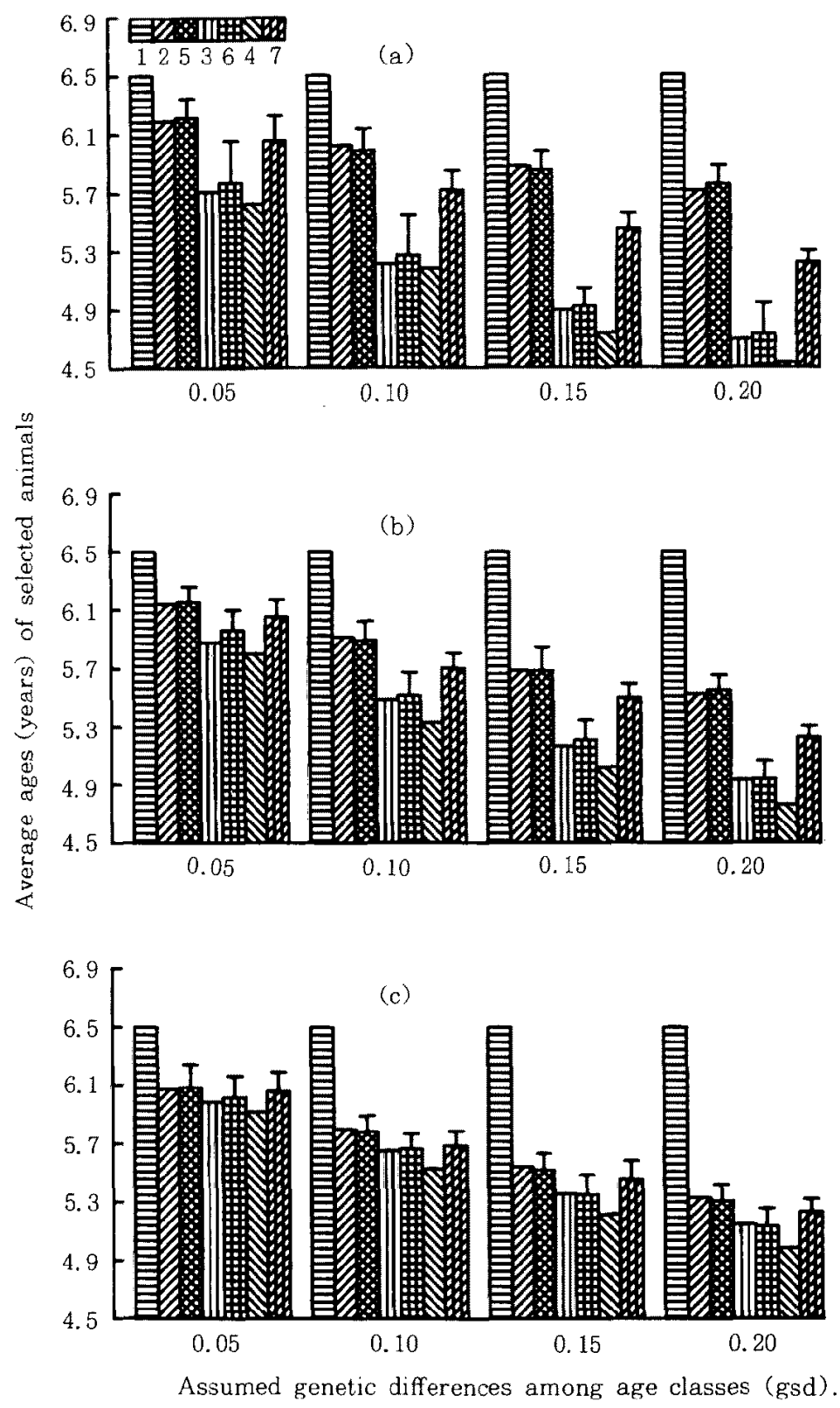

Fig. 1. Average ages of animals selected as bulls' dams through seven truncation selection schemes with accuracy of selection 0.5 (a), 0.7 (b) and 0.9 (c).

I; standard error

ages of selected animals between SS 2 and SS 5 , and SS 3 and SS 6 were relatively large but within the ranges of standard error (Fig. 2). Good agreement between the average ages computed in SS 2 and SS 5, and SS 3 and SS 6 on both paths of selection confirmed their respective algorithms.

Average ages on the path of bulls' dams 


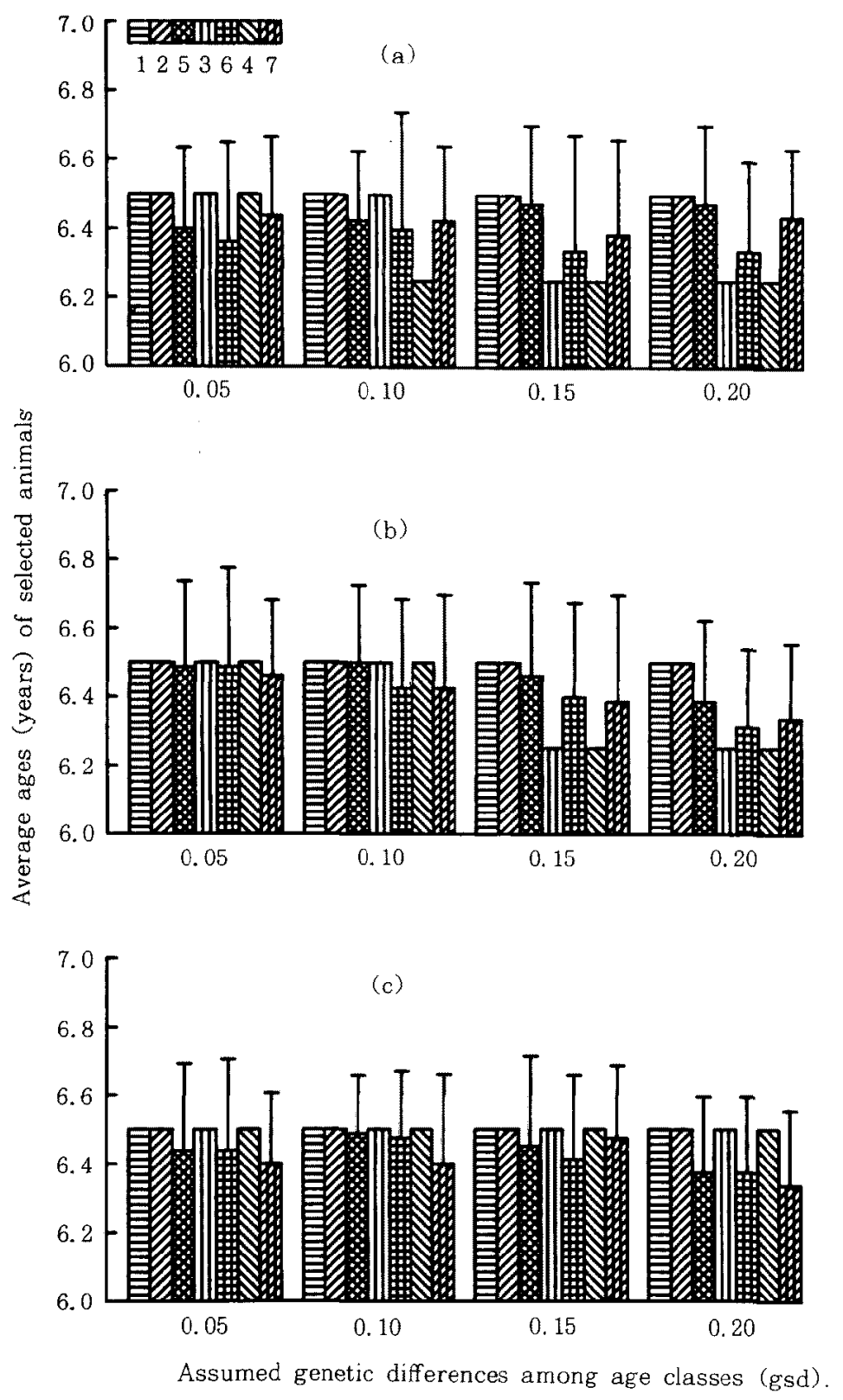

Fig. 2. Average ages of animals selected as bulls' sires through seven truncation selection schemes with accuracy of selection 0.5 (a), 0.7 (b) and 0.9 (c).

I ; standard error

became younger with the expansion of genetic differences among age classes through all schemes except SS 1 , due to its framed definition, for any value of accuracy of selection.
The increase in accuracy decreased the average ages of selected animals in SS 2 or SS 5 and increased average ages in SS 3, SS 4 and SS 6 (Fig. 1.a, b, c) for any level of genetic differ- 

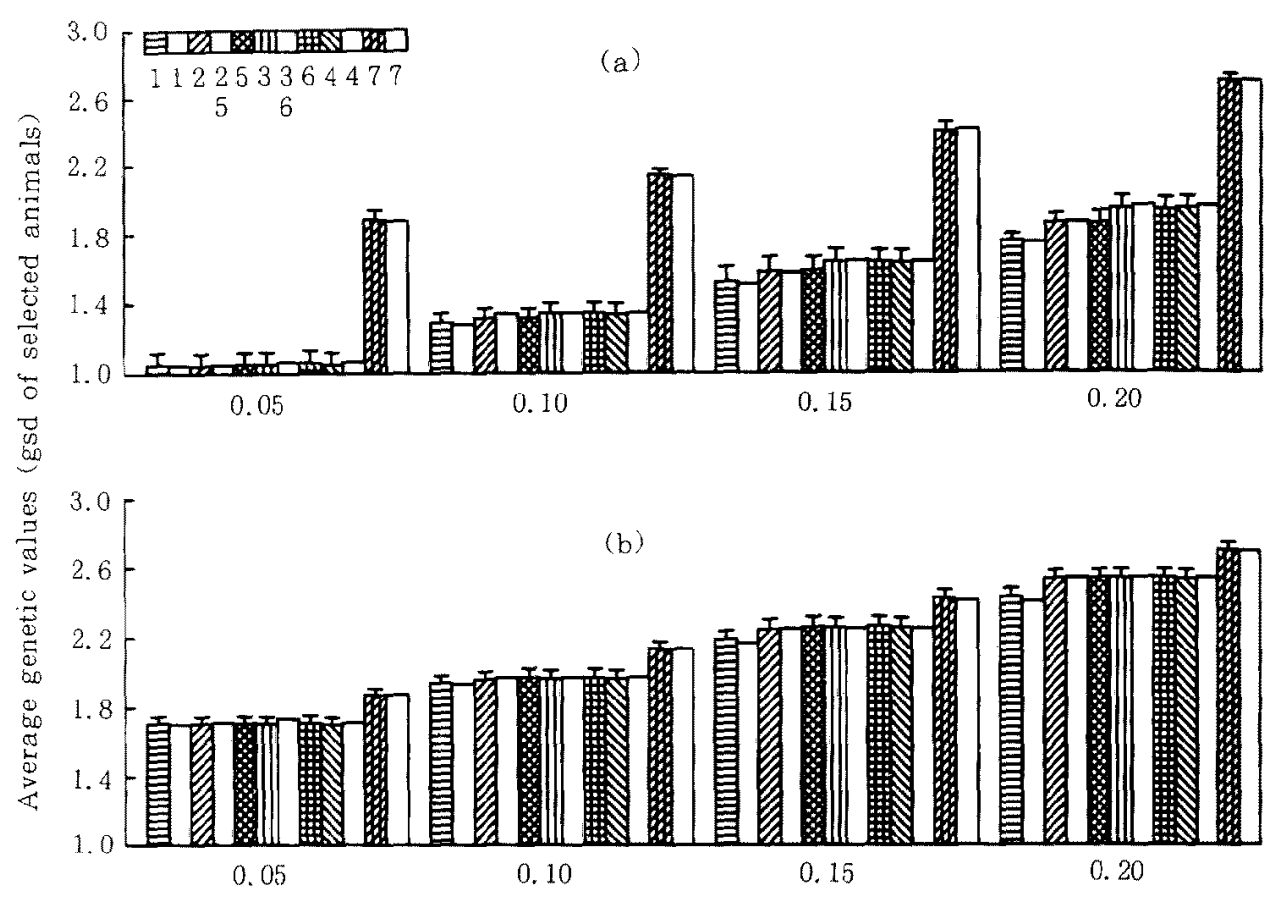

Assumed genetic differences among age classes (gsd).

Fig. 3. Theoretical and simulated average genetic values of animals selected as bulls' dams through seven truncation selection schemes with accuracy of selection 0.5 (a) and 0.9 (b).

I ; standard error

$\square$; Theoretical genetic values for earmarked schemes

ences among age classes. The average ages on the path of bulls' sires also exhibited a similar tendency, with large standard errors, as augmenting the genetic differences and accuracy of selection, though the tendency at low accuracy $(r=0.5)$ was not very clear.

Overall, the average ages were youngest in SS 4 followed SS 3 or SS 6 , and SS 2 or SS 5 and SS 1 on both paths of selection for any combination of variable factors. The average ages in SS 7 were in between the SS 2 or SS 5 and SS 3 or SS6. The differences among schemes became apparently large as increasing the gentic differences among age classes and decreasing the accuracy of selection, however, unlike with bulls' dams, large standard errors were observed on the path of bulls' sires.

Genetic values of selected animals: The theoretical and simulated average genetic values of selected animals through 7 selection schemes for the path of bulls' dams and bulls' sires are presented in Fig. 3 and 4 respectively. On the path of bulls' dams where numbers of potential candidates and selected animals were comparatively large, simulated genetic values coincided with the theoretical genetic values in all schemes. Realized average genetic values in SS 5 and SS 6 were also in good agreement with those of SS 2 and SS 3, respectively. On the path of bulls' sires where numbers of potential candidates and selected animals were comparatively small, some deviations in realized average genetic values from theoretical values were found within the ranges of standard error over the repetition of simulation. These good agreements within the wide ranges 


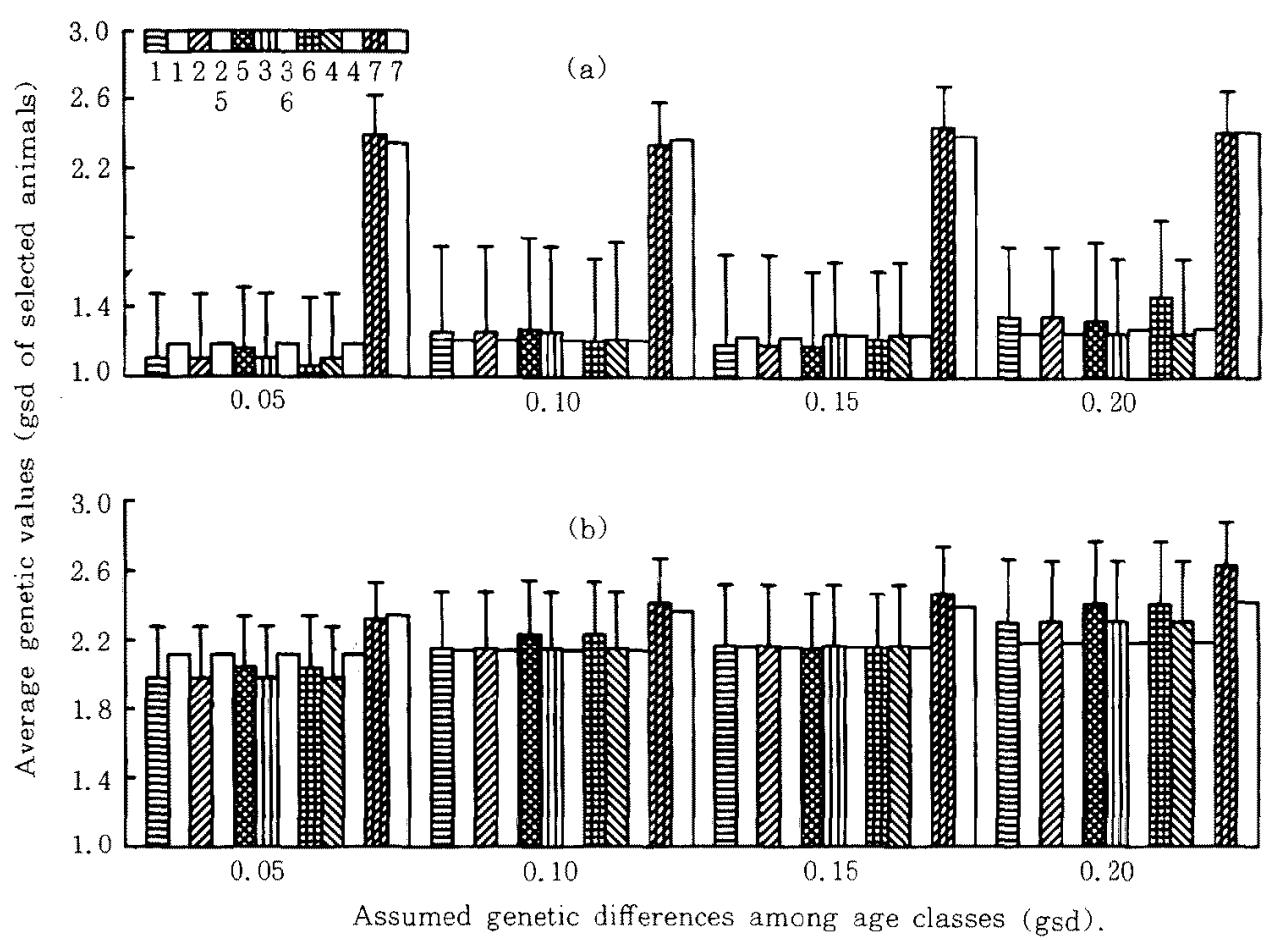

Fig. 4. Theorctical and simulated average genetic values of animals selected as bulls' sires through seven truncation selection schemes with accuracy of selection 0.5 (a) and 0.9 (b).

I; standard error

$\square$; Theoretical genetic values for earmarked schemes

of assumed parameters used in this study confirmed the proposed algorithms. The simulated and theoretical average genetic values of selected animals differed more among schemes with expanded genetic differences among age classes. On the contrary, an increase in the accuracy of selection decreased the differences among selection schemes for both paths of selection.

Average genetic values in SS 3, SS 6 and SS 4 were always higher compared with others (SS 1 and SS 2 or SS 5) except for SS 7 over any combination of variable factors, but the differences between SS 3 or SS 6 and SS 4 were very small. This tendency was clearly exhibited for large genetic differences $(0.15-0.20)$ among age classes and low accuracy of selection $(\mathrm{r}=0.5)$ on the path of bulls' dams
(Fig. 3). However, on the path of bulls' sires, some discrepencies from this tendency were found (Fig. 4) due to larger sampling errors. The theoretical and simulated mean genetic values either coincided or manifested a slight variation in all schemes on both paths of selection.

The standard error in simulated average genetic values ranges from 0.03 to 0.07 on the path of bulls' dams in all schemes (Fig. 3). However, the standard error in simulated values on the path of bulls' sires were large; hardly less than 0.25 for all schemes except SS 7 where these values were not greater than 0.25 (Fig. 4).

\section{Discussion}

The main objective of this study was to 


\section{Ghaffar and Shimizu}

verify whether the previously proposed algorithms for predicting the age structures and genetic values of selected animals could be used in truncation selection schemes. It is clear from the results that the theoretical and numerical values for average ages and genetic values of selected animals were in good agreement within the wide ranges of assumptions. This reality confirmed the proposed algorithms concerning the selection within or across age classes in a population with overlapping generations.

Tsuruta et al. ${ }^{13)}$ reported that the yearly genetic improvement in milk yield in Hokkaido dairy cattle population was $88.1 \mathrm{~kg}$ from 1981 through 1986. This gain is equal to 0.12 genetic standard deviation units, assuming genetic standard deviation to be $750 \mathrm{~kg}$. This value of genetic gain is within the ranges of assumed constant genetic difference among age classes, though variation in the early years has been reported by some authors ${ }^{7,8)}$. When the genetic abilities of cows are evaluated through BLUP procedures ${ }^{6)}$ with an animal model using all available information and considering the $\mathrm{h}^{2}$ to be 0.25 , the accuracy of selection would be higher than 0.5 for the youngest age class of cows having only one lactation record and the increment in accuracy of selection will decrease with the aging of cows. The selection of bulls' dams based on estimated breeding values is equivalent to SS 3 or SS 6 in this study. This was revealed that increasing the accuracy of selection, constant among age classes, causes the average ages of selected animals to be older in SS 3 or SS 6 and SS 4 and younger in SS 2 or SS 5. These findings led to the suspicion of underprediction of the average ages in SS 3 and SS 4 and overprediction in SS2. However, apparent differences between SS 1 and other schemes, even when the accuracy of selection was taken as 0.9 (Fig. 1), suggested that the described algorithms would be useful to predict average ages, especially on the path of bulls' dams in the respective schemes. On the path of bulls' sires, where only 2 age classes were considered with a few selected animals, the sampling error dominated over the differences among the schemes (Fig. 2).

The average ages of parents at the birth of selected animals were taken as generation length, hence, the effects of selection across age classes would be placed in generation length and not in the genetic values as described by $\mathrm{JAMES}^{9}$. . This heuristic argument elucidates why the genetic values among the schemes did not differ significantly. The average ages were younger in the schemes operated on predicted breeding values (SS 3 or SS 6 and SS 4) and consequently the yearly genetic improvement would be higher in these schemes. The conclusion that selection on predicted breeding value manifested younger average ages is in agreement with those of BICHARD et al. ${ }^{13}$ and JAMEs ${ }^{10)}$. Moreover, SS 4 exhibited more promising results in terms of higher yearly genetic improvement owing to youngest ages though differences in average genetic values among SS 3 or SS 6 and SS 4 were small.

The results of this simulation study were computed at the Hokkaido University Computing Center.

\section{References}

1) Bichard, M., A.H.R. Pease, P.H. Swales and K. ÖzKüTüK, Selection in a population with overlapping generations. Anim. Prod., 17 : 215-227. 1973.

2) Dickerson, G.E. and L.N. Hazel, Effectiveness of selection on progeny performance as a supplement to earlier culling of livestock. J. Agr. Res., 69: 459-476. 1944.

3) Ducroca, V. and R.L. QuaAs, Prediction of genetic response to truncation selection across generations. J. Dairy Sei., 71 : 25432553. 1988.

4) Fisher, R.A. and F. YATES, Statistical Tables for Biological and Medical Research. 6th ed. Oliver and Boyd, Edin- 
burugh. 1963.

5) Ghaffar, A.,H. Shimizu, Bias in parental age structure ascribed to non-optimized across the age classes selection in a dairy population with overlapping generations. Anim. Sci. Technol. (Jpn.), 63: 924-927. 1992.

6) Henderson, C.R. and R.L. QuaAs, Multiple traits evaluation using relatives' records. J. Anim. Sci., 43 : 1188-1197. 1976.

7) HuLL, W.G., Selection with overlapping generations. in Proceedings of the International Conference on Quantitative Genetics. (Pollak, E., O. Kempthorne and T.B. Balley, Jr.) 367-378. Iowa State Univ. Press. Ames. 1977.

8) Hopkins, I.R. and J.W. JAMES, Genetic responses in the early years of selection programmes using genetic differences between generations. Anim. Prod., 28:6577. 1979 .
9) JAMES, J.W., A note on selection differential and generation length when generations overlap. Anim. Prod., 24: 109-112. 1977.

10) JAMES, J.W., Determination of optimal selection policies. J. Anim. Breed. Genet., 104: 23-27. 1987.

11) Rendel, J.M. and A. Robertson, Estimation of genetic gain in milk yield by selection in a closed herd of dairy cattle. $\mathrm{J}$. Genetics, 50: 1-8. 1950.

12) Shimizu, $H$. and A. Ghaffar, Truncation selection points in a popuation with overlapping generations. Anim. Sci. Technol. (Jpn.), $63:$ 1109-1114. 1992.

13) Tsuruta, S., M. Suzuki and T. Mitsumoto, Estimation of genetic and environmental trends from simultaneous genetic evaluation of bulls and cows using Hokkaido Dairy Herd Milk Records. Jpn. J. Zootech. Sci., 61 : 1051-1056. 1990.

\title{
世代重複集団における年齢群内・間選抜に関する 理論の数值実験による検証
}

\author{
Abdul GHAFFAR • 清水 弘 \\ 北海道大学農学部，札幅市北区 060
}

\begin{abstract}
世代重複集団において，年齢群を越えての予測育種価に基つく選拔と，選拔種畜の平均育種価が年歯 群間で等しくなる選抜を実施した時の選抜種畜の年路構成と遺伝的優越差を予測する演算法を先に提示 したが，モンテカルロ法による模擬選报実験によって家音集団へのその適用性を検証した，集団の大き さ, 年齢群数の影響を考虑し，锺雄牛父牛（選抜割合 $4 / 200$, 年齢群数 2）と喠雄牛母牛 (200/1600, 8) の 2 選拔经路，選抜の正確度（3 水準；0.5，0.7，0.9)，年踰群間の平均能力差（4 水準；0.05，0.10，

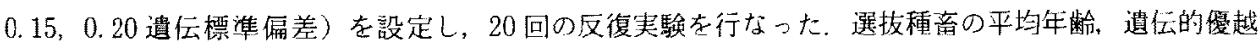
差とそれらの变動（誤差）を算出し，理論值と比較した，候補畜ならびに選拔種畜数ともに比較的多い 種雄牛母牛経路では，平均年㱓，遣伝的優越差とも計算值と理論值とはよく一致した。また，頭数肪少 ない種雄生父牛経路では理論值との間に差が認められたが，䛊差の渻囲内であった．年踰群間差と選拢 の正確度を広い範囲に設定しても計算值と理諭值とがよく一致したことは，提示した演算法が家畜集団 に適用できることを実証している，表現型值での選抜と比較したとき，年制群間の遣伝的差が大きく選 扳の正碎度が低くなるに連れて，年路構成と選抜種畜の遺伝優越差での差は大きくなる傾向を示した。
\end{abstract}

日畜会報，64 (8)：771-779, 1993 